\title{
The diagnostic value of irisin in patients with acute abdominal pain: A preliminary study
}

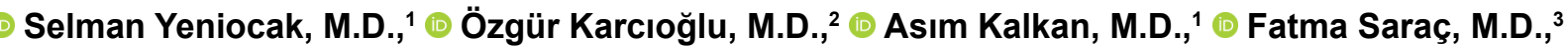 \\ Gökçe Akgül Karadana, M.D., ${ }^{4}$ ¿ Zehra Zeynep Keklikkıran, M.D., ${ }^{5}$ ๑ Alper Gümüş, M.D., ${ }^{6}$

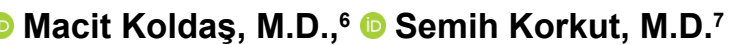

\begin{abstract}
${ }^{1}$ Department of Emergency, University of Health Sciences, Haseki Training and Research Hospital, İstanbul-Turkey 2Department of Emergency, University of Health Sciences, İstanbul Training and Research Hospital, İstanbul-Turkey ${ }^{3}$ Department of Pediatric Surgery, University of Health Sciences, Haseki Training and Research Hospital, İstanbul-Turkey 4Department of Emergency Medicine, Koç University Faculty of Medicine, İstanbul-Turkey

${ }^{5}$ Department of General Surgery, University of Health Sciences, Haseki Training and Research Hospital, İstanbul-Turkey ${ }^{6}$ Department of Clinical Chemistry, University of Health Sciences, Haseki Training and Research Hospital, İstanbul-Turkey ${ }^{7}$ Department of Emergency, University of Health Sciences, İstanbul Kartal Dr. Lütfi Kırdar Training and Research Hospital İstanbul-Turkey
\end{abstract}

\begin{abstract}
BACKGROUND: The aim of this study was to investigate the prognostic value of irisin by examining the serum level of this smooth muscle protein in patients presenting at the emergency department (ED) with acute abdominal pain.

METHODS: This research was performed as a single-center, prospective, cross-sectional study. In all, 213 adult patients presenting at the ED with acute abdominal pain and I 40 healthy controls were enrolled. The serum irisin level was correlated with the leukocyte, C-reactive protein, amylase, and creatine kinase values. The irisin level was compared between groups of those who were admitted or discharged, and those who received surgical or medical treatment.

RESULTS: The mean irisin level of the 213 patients and the 140 controls was $6.81 \pm 3.17 \mathrm{mcg} / \mathrm{mL} \mathrm{vs}$. $5.69 \pm 2.08 \mathrm{mcg} / \mathrm{mL}$. The mean irisin value of the hospitalized patients $(7.98 \pm 3.11 \mathrm{mcg} / \mathrm{mL})$ was significantly higher than that of the discharged patient group $(6.38 \pm 3.09 \mathrm{mcg} / \mathrm{mL})$ and the controls (control vs. discharged: $p=0.202$; control vs. hospitalized: $p<0.00$ I; discharged vs. hospitalized: $\mathrm{p}=0.00 \mathrm{I}$ ). When compared with that of the control group, the irisin level was significantly higher in patients with gall bladder diseases, urolithiasis, and acute appendicitis $(p=0.001, p=0.007, p=0.007)$.
\end{abstract}

CONCLUSION: The serum irisin level in patients with abdominal pain may serve as a guide in diagnostic decision-making and determining the prognosis for cases of acute abdominal pain involving luminal obstruction in tubular intra-abdominal organs.

Keywords: Acute abdominal pain; emergency department; irisin; outcome.

\section{INTRODUCTION}

Patients with abdominal pain represent a group frequently seen in the emergency department (ED). A differential diagnosis of a patient with acute abdominal pain is the duty and responsibility of the emergency physician. Various markers are useful. Laboratory test results, in addition to the patient's history and physical examination results, significantly facilitate diagnosis. New markers are also regularly announced, and these can serve as guides in the diagnosis of abdominal pain. ${ }^{[1]}$ Biochemical markers, such as D-dimer and C-reactive protein (CRP), have been studied in the differential diagnosis of patients with acute abdominal pain, particularly those requiring surgical intervention, and these parameters have been

Cite this article as: Yeniocak S, Karcıoğlu Ö, Kalkan A, Saraç F, Akgül Karadana G, Keklikkıran ZZ, et al. The diagnostic value of irisin in patients with acute abdominal pain: A preliminary study. Ulus Travma Acil Cerrahi Derg 2018;24:539-544.

Address for correspondence: Selman Yeniocak, M.D.

Sağılık Bilimleri Üniversitesi, Haseki Eğitim ve Araştırma Hastanesi, Acil Tıp Kliniği, İstanbul, Turkey.

Tel: +90 212 - 5294400 E-mail: selmanyeniocakacil@hotmail.com

Ulus Travma Acil Cerrahi Derg 2018;24(6):539-544 DOI: 10.5505/tjtes.2018.29235 Submitted: 12.0I.2018 Accepted: 26.07.2018 Online: 28.1I.2018

Copyright 2018 Turkish Association of Trauma and Emergency Surgery 
reported to be potential markers of the need for surgery in patients with undiagnosed acute abdominal pain. ${ }^{[2]}$

Irisin is recognized as an exercise hormone originating from skeletal muscle. ${ }^{[3]}$ In addition to skeletal muscle, it is also produced in other sites, such as fat, the liver, the heart, and salivary gland tissues. ${ }^{[4-6]}$ Irisin is a version of the fibronectin type III domain-containing 5 (FNDC5) protein, which regulates the release of irisin from muscle cells. ${ }^{[7]}$ The irisin precursor FNDC5 mRNA has been reported to be released from tissues such as the ovaries, the adrenal gland, the vena cava, the kidney, the urethra, the bladder, the liver, and the small intestines. ${ }^{[4]}$

Bakal et al. ${ }^{[8]}$ reported increased irisin levels in cases of acute appendicitis (AA). The purpose of the present study was to assess whether adding measurement of the blood irisin level to the routine blood work-up would be useful in establishing a diagnosis in patients presenting with acute abdominal pain.

\section{MATERIALS AND METHODS}

\section{Study Design and Setting}

This research was performed as a single-center, prospective, and cross-sectional study. Following receipt of ethics committee approval (Haseki Training and Research Hospital (2016/297), patients presenting at the ED with non-specific acute abdominal pain were reviewed for inclusion in the study. This hospital ED treats approximately 200,000 patients a year. Approximately $2 \%$ of these patients present with abdominal pain.

\section{Participants}

Patients aged 18 years or more and presenting at the ED with acute abdominal pain ongoing for fewer than 7 days were included in a 3-month study. The only eligibility criteria were age and presentation with acute abdominal pain at the ED. The participants were enrolled by the emergency physician on duty based on the chief complaint. Pregnant patients, and those determined to have liver failure, anorexia nervosa, acute myocardial infarction (AMI) or ischemic heart disease, metabolic syndrome, or diabetes mellitus, which might affect blood irisin levels, and those under 18 years of age were excluded. A total of I 40 healthy volunteers were also recruited as a control group for the study.

Sex, age, weight, height, length of time of pain until presentation at the ED, and blood leukocyte, CRP, amylase, and creatine kinase $(C K)$ values of patients were recorded on patient forms. The blood irisin level was expressed as microgram/ milliliter $(\mathrm{mcg} / \mathrm{mL})$ and the level observed in the patient and control groups was compared. The patients were diagnosed on the basis of anamnesis, physical examination, biochemical blood tests, and radiological imaging, as well as operation specimens collected from patients undergoing surgery following the requisite consultations.

\section{Blood Irisin Measurements}

Human irisin enzyme-linked immunosorbent assay kits (Catalog No. CK-E90905; Hangzhou Eastbiopharm Co., Ltd., Hangzhou, China) were used to determine irisin levels, according to the manufacturer's instructions. Specimen absorbance was determined using a Biotek ELX800 microplate reader (Biotek Instruments, Inc., Winooski, VT, USA) at a wavelength of $450 \mathrm{~nm}$. The results were expressed in $\mu \mathrm{g} / \mathrm{mL}$. The minimum detectable level was $0.05 \mu \mathrm{g} / \mathrm{mL}$.

\section{Statistical Analysis}

Statistical analysis was performed using SPSS for Windows, Version I5.0 (SPSS Inc., Chicago, IL, USA) software. Descriptive data were expressed as numbers and percentages for categorical variables, and as mean, SD, minimum, maximum, and median for numerical variables. Student's t-test was used for comparisons between 2 groups of numerical variables when normal distribution conditions were established, and the Mann-Whitney $U$ test was applied when normal distribution was not established. One-way analysis of variance and the Kruskal-Wallis test were used for comparisons between more than 2 groups. Subgroup analyses of comparisons of more than 2 groups were performed using the Mann-Whitney $U$ test with a Bonferroni correction. Correlations between numerical variables were examined using Spearman correlation analysis since parametric test conditions were not established. $\mathrm{P}<0.05$ was regarded as statistically significant.

The sample size was calculated to be of sufficient size to predict a small to medium-size effect in the difference of irisin levels in 2 independent groups with an alpha-error of 0.05 and $95 \%$ power.

\section{RESULTS}

A total of 213 patients and a 140-member healthy control group were included in the study. In all, 185 patients were excluded for following reasons: pregnancy $(n=16)$, liver failure $(n=7)$, anorexia nervosa $(n=3)$, ischemic heart disease $(n=35)$, metabolic syndrome or diabetes mellitus $(n=37)$, and those who declined to participate in the study $(n=85)$.

The patient group consisted of 119 men (55.9\%) and 94 women $(44.1 \%)$, with a mean age of $42.9 \pm 19$. I years (median: 40 years, range: 18-87 years). The control group consisted of 74 men $(52.9 \%)$ and 66 women (47.1\%) with a mean age of $44.7 \pm 18.8$ years (median: 42 years, range: 18-87 years). The mean length of time between the onset of pain and presentation at the ED was $22.6 \pm 14.8$ hours (median: 24 hours, range: 3-72 hours). The patients' general characteristics and parameter values are shown in Table I.

The mean leukocyte value in the patient group was I I.423. I $\pm 4978.6 \mathrm{~mm}^{3}$, the mean CRP level was $528.5 \pm 6179$.I $\mathrm{mg} / \mathrm{L}$, the mean amylase value was $117.6 \pm 275.8 \mathrm{U} / \mathrm{L}$, and the 
Table I. Patients' general characteristics and laboratory values

\begin{tabular}{|c|c|c|c|c|}
\hline & $\mathbf{n}$ & $\%$ & Mean $\pm S D$ & Range/Median \\
\hline \multicolumn{5}{|l|}{ Gender } \\
\hline Male & 119 & 55.9 & & \\
\hline Female & 94 & 44.1 & & \\
\hline Age (years) & & & $42.9 \pm 19.1$ & $18-87 / 40$ \\
\hline Body mass index $\left(\mathrm{kg} / \mathrm{m}^{2}\right)$ & & & $26.2 \pm 3.6$ & $18.3-37.1 / 26.2$ \\
\hline Pre-presentation pain duration (hours) & & & $22.6 \pm 14.8$ & $3-72 / 24$ \\
\hline Leukocyte $\left(\mathrm{mm}^{3}\right)$ & & & $\mid I .423 .1 \pm 4978.6$ & $3650-28.470 / 10.160$ \\
\hline C-reactive protein (mg/L) & & & $43.12 \pm 78.59$ & $0.14-419.1 / 8.07$ \\
\hline Amylase (U/L) & & & $117.6 \pm 275.8$ & $|4.6-24||| / .63 . \mid$ \\
\hline Creatine kinase (U/L) & & & $266.2 \pm 1569.4$ & II-22.767.6/96.9 \\
\hline Irisin $(\mathrm{mcg} / \mathrm{mL})$ & & & $6.81 \pm 3.17$ & $0.16-13.59 / 6.47$ \\
\hline
\end{tabular}

mean CK value was $266.2 \pm 1569.4 \mathrm{U} / \mathrm{L}$. The irisin level in the patient group was significantly positively correlated with the amylase value among the general characteristics and parameters $(p=0.028)$. No statistically significant association was determined with the leukocyte, CRP, or CK level $(p=0.788$, $p=0.200$, and $p=0.807$, respectively).

The patients' mean body mass index (BMI) was $26.2 \pm 3.6 \mathrm{~kg} /$ $\mathrm{m}^{2}$ (median: $26.2 \mathrm{~kg} / \mathrm{m}^{2}$, range: $18.3-37.1 \mathrm{~kg} / \mathrm{m}^{2}$ ). The mean $\mathrm{BMl}$ among members of the control group was $25.5 \pm 3.4 \mathrm{~kg} /$ $\mathrm{m}^{2}$ (median: $25.6 \mathrm{~kg} / \mathrm{m}^{2}$, range: $18.4-36.1 \mathrm{~kg} / \mathrm{m}^{2}$ ). The difference between the mean $\mathrm{BMI}$ value of the patient and control groups was not statistically significant $(p=0.074)$.

The mean irisin value in the patient group was $6.8 \pm 3.2 \mathrm{mcg} /$ $\mathrm{mL}$ (range: $0.2-13.6 \mathrm{mcg} / \mathrm{mL}$ ), compared with $5.7 \pm 2.1 \mathrm{mcg} /$ $\mathrm{mL}$ (range: $0.2-10.5 \mathrm{mcg} / \mathrm{mL}$ ) in the control group. The difference between the mean irisin level in the patient group and the control group was statistically significant $(p=0.005)$. However, no statistically significant difference was determined

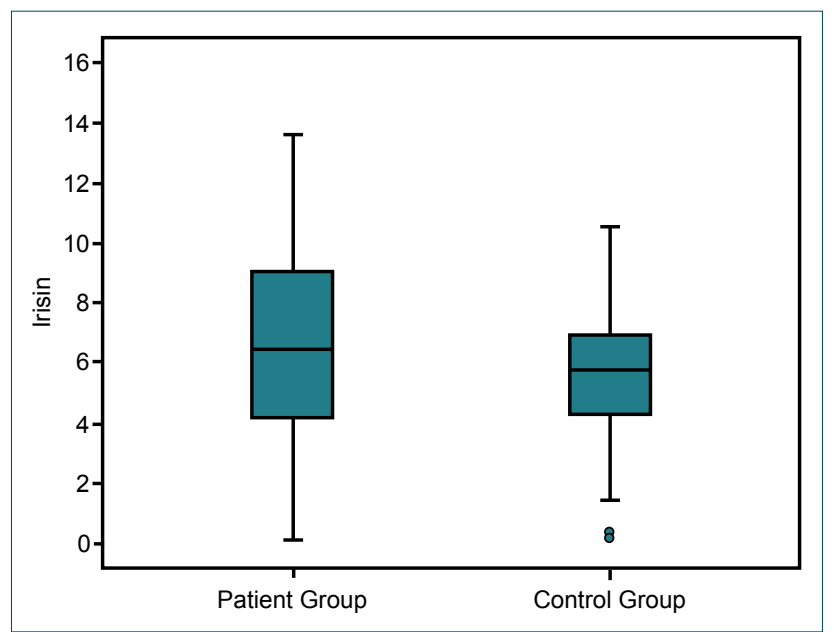

Figure 1. Patients' irisin values. in the mean irisin level when analyzed according to gender $(p=0.108)$ (Table 2, Fig. I).

When the irisin level in the patient group was compared with that of the control group, the irisin level in the patient group was determined to be significantly higher in those with AA (Mean $\pm S D$ : $8.59 \pm 3.61 \mathrm{mcg} / \mathrm{mL}$, range: $6.67-10.51 \mathrm{mcg} /$ $\mathrm{mL}$ ), urolithiasis (Mean $\pm \mathrm{SD}: 7.55 \pm 3.07$, range: 6.38-8.72) and gallbladder subgroups (Mean $\pm S D$ : $7.57 \pm 2.49$, range: $6.5 \mathrm{I}-$ 8.62) compared with the control group $(p=0.007, p=0.007$, $\mathrm{p}=0.00 \mathrm{I})$. Diagnoses in the ED demonstrating prevalence and irisin level are provided in Table 3 and Figure 2.

\section{DISCUSSION}

The blood irisin level of patients presenting with acute abdominal pain was significantly higher compared with that of the healthy control group in this study. Analysis of the diagnostic subgroups revealed that the blood irisin level was higher in the patients with AA, biliary colic, and colic in the urinary tract than in the control group. Higher blood levels

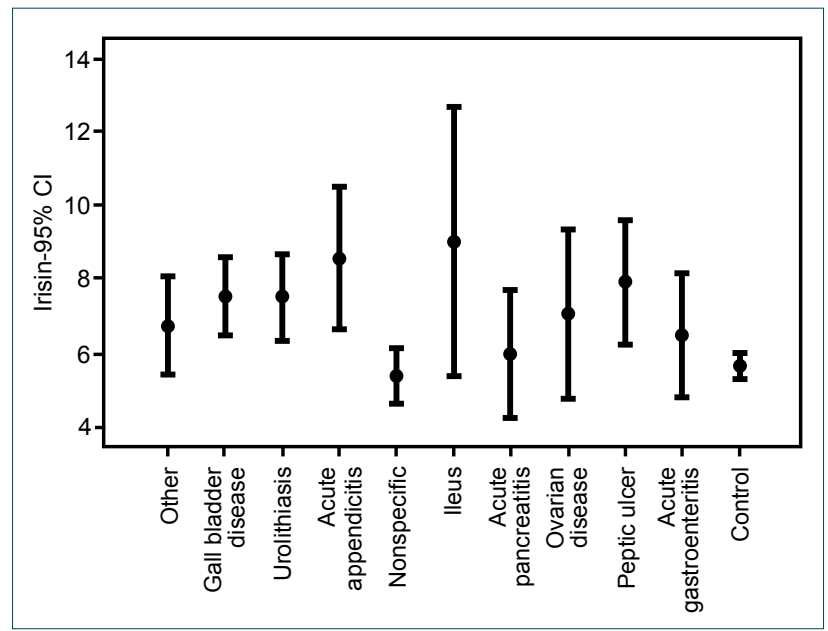

Figure 2. Irisin values by patient group. 
Table 2. Distribution of patient and control group cases by gender and irisin level

\begin{tabular}{|c|c|c|c|c|c|c|c|c|c|}
\hline & \multicolumn{4}{|c|}{ Patients } & \multicolumn{4}{|c|}{ Control group } & \multirow[t]{2}{*}{$\mathbf{p}$} \\
\hline & $\mathbf{n}$ & $\%$ & Mean $\pm S D$ & Range/Median & $\mathbf{n}$ & $\%$ & Mean $\pm S D$ & Range/Median & \\
\hline \multicolumn{10}{|l|}{ Gender } \\
\hline Male & 119 & 55.9 & & & 74 & 52.9 & & & 0.108 \\
\hline Female & 94 & 44.1 & & & 66 & 47.1 & & & \\
\hline Irisin & & & $6.81 \pm 3.17$ & $0.16-13.59 / 6.47$ & & & $5.69 \pm 2.08$ & $0.18-10.54 / 5.78$ & 0.005 \\
\hline
\end{tabular}

Table 3. Diagnoses in the emergency department (in order of prevalence) and irisin level

\begin{tabular}{|c|c|c|c|c|c|c|c|c|}
\hline & & \multicolumn{7}{|c|}{ Irisin } \\
\hline & & $\mathbf{N}$ & $\%$ & Mean & SD & Median & $95 \% \mathrm{Cl}$ & Range \\
\hline Control & & 140 & & 5.69 & 2.08 & 5.78 & 5.34 & 6.04 \\
\hline \multirow[t]{21}{*}{ Diagnosis } & Nonspecific & 68 & 31.92 & 5.42 & 3.02 & 5.09 & 4.69 & 6.15 \\
\hline & Urolithiasis & 29 & 13.62 & 7.55 & 3.07 & 7.12 & 6.38 & 8.72 \\
\hline & Gall bladder disease & 24 & 11.27 & 7.57 & 2.49 & 7.31 & 6.51 & 8.62 \\
\hline & Peptic ulcer & 17 & 7.98 & 7.95 & 3.25 & 7.51 & 6.28 & 9.62 \\
\hline & Acute appendicitis & 16 & 7.51 & 8.59 & 3.61 & 8.61 & 6.67 & 10.51 \\
\hline & Acute gastroenteritis & 13 & 6.10 & 6.52 & 2.75 & 5.99 & 4.86 & 8.18 \\
\hline & Ovarian disease & 10 & 4.69 & 7.08 & 3.18 & 7.14 & 4.81 & 9.36 \\
\hline & lleus & 6 & 2.82 & 9.04 & 3.46 & 8.93 & 5.41 & 12.67 \\
\hline & Acute pancreatitis & 6 & 2.82 & 6.00 & 1.63 & 6.40 & 4.29 & 7.72 \\
\hline & Other & 24 & 11.27 & 6.79 & 3.13 & 7.17 & 5.47 & 8.11 \\
\hline & Gastrointestinal mass ${ }^{*}$ & 4 & 1.88 & 6.57 & 1.79 & 7.24 & & \\
\hline & Hernia* & 4 & 1.88 & 5.09 & 4.53 & 4.83 & & \\
\hline & Small bowel disease* & 4 & 1.88 & 6.35 & 3.24 & 6.02 & & \\
\hline & Gl perforation* & 3 & 1.41 & 6.54 & 2.29 & 7.59 & & \\
\hline & Urinary infection ${ }^{*}$ & 3 & $\mathrm{I} .4 \mathrm{I}$ & 5.73 & 1.76 & 5.80 & & \\
\hline & Abdominal aortic aneurysm* & 1 & 0.47 & 12.43 & - & 12.43 & & \\
\hline & Abdominal abscess" & 1 & 0.47 & 5.10 & - & 5.10 & & \\
\hline & Splenic infarction* & 1 & 0.47 & 7.91 & - & 7.91 & & \\
\hline & Familial Mediterranean fever* & 1 & 0.47 & 12.18 & - & 12.18 & & \\
\hline & Mesenteric ischemia ${ }^{*}$ & 1 & 0.47 & 11.42 & - & 11.42 & & \\
\hline & Mesenteric lymphadenitis* & 1 & 0.47 & 5.01 & - & 5.01 & & \\
\hline
\end{tabular}

*Included in the analysis as the "other" group. SD: Standard deviation; Cl: Confidence interval.

in patients with diseases involving narrowing or obstruction of the tubular appendix vermiformis or the urinary or biliary tract suggested that irisin may be a potential marker in the diagnosis of these diseases. Bakal et al. ${ }^{[8]}$ investigated the irisin level in blood, urine, and saliva in pediatric patients with AA. They also used immunohistochemical methods to determine the blood irisin level in diseased appendix vermiformis tissue. Patients with AA had a higher irisin level compared with the control group. When they followed up with these patients after surgery, they observed a dramatic drop in the irisin level. They suggested that irisin together with an increase in neutrophil level might be a good marker in cases of AA. The results reported by Bakal et al. support our own research. The blood irisin level in patients diagnosed with AA in our study was higher than that of the control group.

Irisin level has thus far only been investigated in AA among patients with acute abdominal pain, and ours is the first study 
to investigate irisin level in all types of non-traumatic acute abdominal pain. The present study is valuable in terms of determining that there were high blood irisin levels in biliary colic and urolithiasis as well as AA. The determination of a high blood irisin level in the pathology of organs with a tubular structure can assist with the exclusion of other etiological causes of abdominal pain.

Blood irisin level has already been investigated in several diseases. Numerous studies have linked it to muscle mass and insulin resistance, leading to investigation of potential cardiovascular effects. The potential influence in chronic kidney failure, some cancers, metabolic disease, non-alcoholic liver disease, and osteoporosis have also been examined; however, irisin has been assessed more as a hormone than as a biochemical marker. ${ }^{[9]}$ The present study indicates that irisin may be a biochemical marker in some specific groups of conditions featuring abdominal pain.

Aydın et al. ${ }^{[10]}$ investigated the irisin level in serum and saliva in patients who experienced AMI. The serum and saliva levels of irisin measured at the time of presentation and after 72 hours were elevated, while the CK and CK-MB levels were decreased. They suggested that a low irisin level in the early period might be used as a biomarker to support a diagnosis of AMI. An interesting aspect of that study is that, using immunohistochemistry, they were able to demonstrate that not only the striated muscle of the salivary glands, but also the lumen, was able to secrete irisin. Their study is evidence that some proteins can be produced in the salivary glands and acinar cells.

The common feature of the structures of gastrointestinal, biliary, and urinary tract organs is that they are tubular organs with a smooth muscle structure. ${ }^{[1]}$ The pathophysiology of this diagnostic group of diseases associated with a high irisin level included early luminal narrowing and obstruction in the late phase. Distension occurring due to increasing hydrostatic pressure in the proximal part following obstruction stimulates tubular organ peristalsis. ${ }^{[12-15]}$ This smooth muscle mass with increasing peristalsis can be postulated to give rise to increased irisin production either itself, or through interaction with other autocrine and endocrine organs under the influence of inflammation caused by the obstruction.

Irisin was once thought to be released only by skeletal muscle, but has since been shown to be secreted by other organs as well. ${ }^{[3,6,16,17]}$ Irisin release in tubular organ diseases may be confirmed with additional immunohistochemical studies. In the present study it was observed that the irisin level in cases of peptic ulcer, a disease of the stomach, which is a tubular organ and part of the gastrointestinal tract with a smooth muscle wall, did not increase compared with the level of the control group. This may have been a result of narrowing or obstruction of the lumen not related to the physiopathology of peptic ulcer. ${ }^{[1,18]}$
No single biomarker would be sufficient to distinguish the inflammatory condition of tubular organs (e.g., AA, renal colic) per se. Nonetheless, the present findings suggest that irisin may be useful in the differential diagnosis. Acar et al. ${ }^{[19]}$ examined many variables, including serum leukocytes, lymphocytes, neutrophils, neutrophil-lymphocyte ratio, and mean platelet volume, in the diagnosis of tubular organ inflammation. They suggested that these biomarkers could be useful parameters to discriminate and diagnose these conditions, since the level was often higher in those with AA or renal colic than that seen in healthy controls. Similarly, the results of the present research also suggest that the irisin value may be useful in the specific diagnosis of patients with acute abdominal conditions.

\section{Limitations}

The major limitation of this study is the small number of patients included in the sample. In addition, the group assessed was limited only to adults with acute abdominal pain who presented at the ED and was not further refined. Another weakness of this study is that irisin levels were not evaluated immunohistochemically. A further limitation is that the blood irisin level was not monitored after our patients were admitted to the ED. We think that future studies on the causes of acute abdominal pain occurring due to tubular organ obstruction will test our findings.

\section{Conclusion}

In conclusion, the blood irisin level may be useful in the differential diagnosis of diseases involving narrowing or obstruction of tubular organs in patients presenting at the ED with acute abdominal pain.

\section{Conflict of interest: None declared.}

\section{REFERENCES}

1. Meisner M. Pathobiochemistry and clinical use of procalcitonin. Clin Chim Acta 2002;323:17-29. [CrossRef]

2. Akyildiz H, Akcan A, Oztürk A, Sozuer E, Kucuk C, Yucel A. D-dimer as a predictor of the need for laparotomy in patients with unclear nontraumatic acute abdomen. A preliminary study. Scand J Clin Lab Invest 2008;68:612-7. [CrossRef]

3. Boström P, Wu J, Jedrychowski MP, Korde A, Ye L, Lo JC, et al. A PGC1$\alpha$-dependent myokine that drives brown-fat-like development of white fat and thermogenesis. Nature 2012;481:463-8. [CrossRef]

4. Huh JY, Panagiotou G, Mougios V, Brinkoetter M, Vamvini MT, Schneider BE, et al. FNDC5 and irisin in humans: I. Predictors of circulating concentrationsin serum and plasma and II. mRNA expression and circulatingconcentrations in response to weight loss and exercise. Metabolism 2012;61:1725-38. [CrossRef]

5. Kuloglu T, Aydin S, Eren MN, Yilmaz M, Sahin I, Kalayci M, et al. Irisin: a potentially candidate marker for myocardial infarction. Peptides 2014;55:85-91. [CrossRef]

6. Roca-Rivada A, Castelao C, Senin LL, Landrove MO, Baltar J, Belén Crujeiras A, et al. FNDC5/irisin is not only a myokine but also an 
adipokine. PLoS One 2013;8:e60563. [CrossRef]

7. Spiegelman BM. Banting Lecture 2012: Regulation of adipogenesis: toward newtherapeutics for metabolic disease. Diabetes 2013;62:1774-82.

8. Bakal U, Aydin S, Sarac M, Kuloglu T, Kalayci M, Artas G, et al. Serum, Saliva, and Urine Irisin with and Without Acute Appendicitis and Abdominal Pain. Biochem Insights 2016;9:11-7. [CrossRef]

9. Gouveia MC, Vella JP, Cafeo FR, Affonso Fonseca FL, Bacci MR. Association between irisin and major chronic diseases: a review. Eur Rev Med Pharmacol Sci 2016;20:4072-7.

10. Aydin S, Aydin S, Kobat MA, Kalayci M, Eren MN, Yilmaz M, et al. Decreased saliva/serum irisin concentrations in the acute myocardialinfarction promising for being a new candidate biomarker for diagnosisof this pathology. Peptides 2014;56:141-5. [CrossRef]

11. Junqueira LC, Carneiro In: J. Aytekin Y, Solakoğlu S, editors. Basic Histology. Nobel Tip Kitapevleri; 2006. p. 207-13.

12. Freeman HJ. Spontaneous free perforation of the small intestine in Crohn's disease. Can J Gastroenterol 2002;16:23-7. [CrossRef]

13. Way LW, Doherty GM. Current Surgical Diagnosis Treatment. 11th ed. New York C: Mcgrav-Hill Companies; 2003. p.595-624.
14. Lewis KS, Whipple JK, Michael KA, Quebbeman EJ. Effect of analgesic treatment on the physiological consequences of acute pain. Am J Hosp Pharm 1994;51:1539-54.

15. Smith DR. Urinary Stone Disease. In: Tanagho EA, McAninch JW editors. General Urology. 14th ed. New York: Appleton \& Lange; 1994.

16. Albayrak S, Atci İB, Kalayci M, Yilmaz M, Kuloglu T, Aydin S, et al. Effect of carnosine, methylprednisolone and their combined applicationon irisin levels in the plasma and brain of rats with acute spinal cordinjury. Neuropeptides 2015;52:47-54. [CrossRef]

17. Aydin S, Kuloglu T, Aydin S, Kalayci M, Yilmaz M, Cakmak T, et al. A comprehensive immunohistochemical examination of the distribution of the fat-burning protein irisin in biological tissues. Peptides 2014;61:1306. [CrossRef]

18. Sezer R. Sindirim Sistemi Hastalıkları. Büyüköztürk K, editör. İç Hastalikları. Istanbul: Nobel Tip Kitapevi; 1992. p.634-62.

19. Acar E, Özcan Ö, Deliktaş H, Beydilli H, Kırlı İ, Alataş ÖD, et al. Laboratory markers has many valuable parameters in the discriminationbetween acute appendicitis and renal colic. Ulus Travma Acil Cerrahi Derg 2016;22:17-22.

\title{
ORIJINAL ÇALIŞMA - ÖZET
}

\section{Akut karın ağrılı hastalarda İrisin'in tanısal değeri: Bir ön çalışma \\ Dr. Selman Yeniocak, ${ }^{1}$ Dr. Özgür Karcıoğlu, ${ }^{2}$ Dr. Asım Kalkan, ${ }^{1}$ Dr. Fatma Saraç, ${ }^{3}$ Dr. Gökçe Akgül Karadana, ${ }^{4}$ Dr. Zehra Zeynep Keklikkıran, ${ }^{5}$ Dr. Alper Gümüş, ${ }^{6}$ Dr. Macit Koldaş, ${ }^{6}$ Dr. Semih Korkut ${ }^{7}$}

\author{
1Sağlık Bilimleri Üniversitesi Haseki Eğitim ve Araştırma Hastanesi, Acil Tıp Kliniği, İstanbul \\ ${ }^{2}$ Sağlık Bilimleri Üniversitesi İstanbul Eğitim ve Araştırma Hastanesi, Acil Tıp Kliniği, İstanbul \\ ${ }^{3}$ Sağlık Bilimleri Üniversitesi Haseki Eğitim ve Araştırma Hastanesi, Çocuk Cerrahisi Kliniği, İstanbul \\ ${ }^{4}$ Koç Üniversitesi Tıp Fakültesi, Acil Tıp Anabilim Dalı, İstanbul \\ ${ }^{5}$ Sağlık Bilimleri Üniversitesi Haseki Eğitim ve Araştırma Hastanesi, Genel Cerrahi Kliniği, İstanbul \\ ${ }^{6}$ Sağlık Bilimleri Üniversitesi Haseki Eğitim ve Araştırma Hastanesi, Biyokimya Anabilim Dalı, İstanbul \\ ${ }^{7}$ Sağlık Bilimleri Üniversitesi İstanbul Kartal Dr. Lütfi Kirdar Eğitim ve Araştırma Hastanesi, Acil Tıp Kliniği, İstanbul
}

AMAÇ: Akut karın ağrısı şikayeti ile acil servise müracaat eden hastalarda düz kas proteini Irisin'in serum düzeyini ölçerek tanısal değerini araştırmak amacıyla bu çalışma yapıldı.

GEREÇ VE YÖNTEM: Bu araştırma, tek merkezli, ileriye yönelik ve kesitsel bir çalışma olarak yapıldı. Akut karın ağrısı şikayeti ile acil servise başvuran 213 erişkin hasta ve 140 kişilik sağıklı kontrol grubu dahil edildi. Serum irisin düzeyleri, lökosit, C-reaktif protein, amilaz ve kreatin kinaz değerleri ile karşılaştırıldı. Serum İrisin düzeyleri, yatışı yapılan ile taburcu olan ve cerrahi ile tıbbi tedavi yapılan gruplar da karşılaştırıldı.

BULGULAR: Çalışmaya dahil edilen 213 hasta ve 140 kontrol grubu ortalama Irisin düzeyleri $6.81 \pm 3.17 \mathrm{mcg} / \mathrm{mL}$ ve $5.69 \pm 2.08 \mathrm{mcg} / \mathrm{mL}$ idi. Hastaneye yatıılan hastaların ortalama Irisin değerleri $(7.98 \pm 3.11 \mathrm{mcg} / \mathrm{mL})$, taburcu edilen hastaların $(6.38 \pm 3.09 \mathrm{mcg} / \mathrm{mL})$ ve kontrol grubu olguların Irisin değerlerinden (kontrol grubu - taburcu hasta grubu $p=0.202$ ) anlamlı derecede yüksekti (kontrol grubu - hastaneye yatırılan grup $p<0.00$ I, taburcu edilen grup - hastaneye yatıılan grup $\mathrm{p}=0.00 \mathrm{I}$ ). Kontrol grubu ile karşılaştıııldı̆ında, safra kesesi hastalıkları, ürolitiyazis ve akut apandisitte irisin düzeyleri anlamlı olarak daha yüksekti ( $p=0.00$ I, $p=0.007, p=0.007)$.

TARTIŞMA: Serum İrisin seviyeleri, düz kas yapısı içeren karıniçi tübüler organların luminal obstrüksiyonu gelişmiş akut karın ağrılı hastalarda tanı ve prognoz belirlemede bir belirteç olarak kullanilabilir.

Anahtar sözcükler: Akut karın ağrısı; acil servis; Irisin; sonuç.

Ulus Travma Acil Cerrahi Derg 20 I8;24(6):539-544 doi: 10.5505/tjtes.20।8.29235 